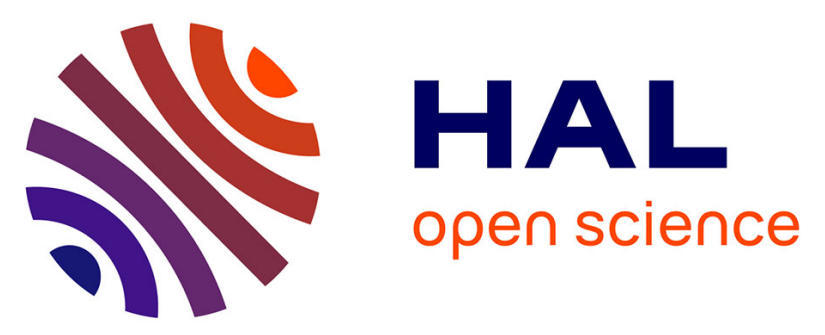

\title{
Thermo-mechanical behaviour of the raffinate resulting from the aqueous extraction of sunflower whole plant in twin-screw extruder: manufacturing of biodegradable agromaterials by thermo-pressing
}

Philippe Evon, Virginie Vandenbossche, Pierre Yves Pontalier, Luc Rigal

\section{To cite this version:}

Philippe Evon, Virginie Vandenbossche, Pierre Yves Pontalier, Luc Rigal. Thermo-mechanical behaviour of the raffinate resulting from the aqueous extraction of sunflower whole plant in twin-screw extruder: manufacturing of biodegradable agromaterials by thermo-pressing. Advanced Materials Research, 2010, vol. 1, pp.63-72. 10.4028/www.scientific.net/AMR.112.63 . hal-00727237

\section{HAL Id: hal-00727237 \\ https://hal.science/hal-00727237}

Submitted on 3 Sep 2012

HAL is a multi-disciplinary open access archive for the deposit and dissemination of scientific research documents, whether they are published or not. The documents may come from teaching and research institutions in France or abroad, or from public or private research centers.
L'archive ouverte pluridisciplinaire HAL, est destinée au dépôt et à la diffusion de documents scientifiques de niveau recherche, publiés ou non, émanant des établissements d'enseignement et de recherche français ou étrangers, des laboratoires publics ou privés. 


\section{Open Archive Toulouse Archive Ouverte (OATAO)}

OATAO is an open access repository that collects the work of Toulouse researchers and makes it freely available over the web where possible.

This is an author -deposited version published in: http://oatao.univ-toulouse.fr/ Eprints ID: 4058

To link to this article: DOI:10.4028/www.scientific.net/AMR.112.63

URL: http://dx.doi.org/10.4028/www.scientific.net/AMR.112.63

To cite this version: Evon, Philippe and Vandenbossche, Virginie and Pontalier, Pierre Yves and Rigal, Luc ( 2010) Thermo-mechanical behaviour of the raffinate resulting from the aqueous extraction of sunflower whole plant in twin-screw extruder: manufacturing of biodegradable agromaterials by thermo-pressing. Advanced Materials Research, vol. 112 . pp. 63-72. ISSN 1022-6680

Any correspondence concerning this service should be sent to the repository administrator: staff-oatao@inp-toulouse.fr 


\title{
Thermo-mechanical behaviour of the raffinate resulting from the aqueous extraction of sunflower whole plant in twin-screw extruder: manufacturing of biodegradable agromaterials by thermo-pressing
}

\author{
Philippe EVON ${ }^{1,2, a}$, Virginie VANDENBOSSCHE ${ }^{1,2, b}$, \\ Pierre-Yves PONTALIER ${ }^{1,2, c}$ and Luc RIGAL ${ }^{1,2, d}$ \\ ${ }^{1}$ Université de Toulouse; INP; LCA (Laboratoire de Chimie Agro-industrielle); \\ ENSIACET, 4 Allée Émile Monso, 31432 Toulouse Cedex 4, France \\ ${ }^{2}$ INRA; LCA (Laboratoire de Chimie Agro-industrielle); 31432 Toulouse Cedex 4, France \\ a Philippe.Evon@ensiacet.fr, ${ }^{b}$ Virginie.VanDenBossche@ensiacet.fr, \\ cPierreYves.Pontalier@ensiacet.fr, ${ }^{d}$ Luc.Rigal@ensiacet.fr
}

\begin{abstract}
Keywords: sunflower, twin-screw extruder, aqueous extraction, lignocellulosic fibres, proteins, natural composite, thermo-pressing, agromaterials.
\end{abstract}

\begin{abstract}
Biorefinery of sunflower whole plant can be realized using a twin-screw extruder. Thermo-mechanical fractionation and aqueous extraction are conducted simultaneously. A filter section is outfitted along the barrel to collect continuously an extract and a raffinate (cake meal). Oil yield obtained is $53 \%$. Proteins are partly extracted at the same time, just as pectins and hemicelluloses. Protein yield is $46 \%$. Cake meal is relatively moist (66\% for the moisture content). It is first dried to make easier its conservation. It is largely composed of lignocellulosic fibres (59\% of the dry matter) from depithed stalk. Lipid content is $13 \%$ of the dry matter or $35 \%$ of the oil in whole plant. Protein content is $7 \%$ of the dry matter or $45 \%$ of the proteins in whole plant. DSC measurements indicate that denaturation of proteins is almost complete in the cake meal. DMTA spectrum of its milled powder reveals a significant peak at high temperature (between 175 and $200^{\circ} \mathrm{C}$ ). As already observed with industrial sunflower cake meal, it can be associated with the glass transition of proteins. As a mixture of fibres and proteins, the cake meal can be considered as a natural composite. It is successfully processed into biodegradable and value-added agromaterials by thermo-pressing. As for DMTA analysis, the glass transition of proteins in the cake meal is also observed with PVT analysis at around $180^{\circ} \mathrm{C}$. It makes easier the choice of the best thermo-pressing conditions to produce panels with higher mechanical properties in bending. These properties increase simultaneously with temperature, pressure and time chosen for molding operation. The highest flexural strength at break $(11.5 \mathrm{MPa})$ and the highest elastic modulus $(2.22 \mathrm{GPa})$ are obtained for the next molding conditions: $200^{\circ} \mathrm{C}$ and $320 \mathrm{kgf} / \mathrm{cm}^{2}$ during $60 \mathrm{~s}$. Drop angle measurements show that the corresponding panel is also the most resistant to water. No significant transition is observed inside this panel above $0^{\circ} \mathrm{C}$ and until $200^{\circ} \mathrm{C}$ with DMTA analysis. Proteins ensure the agromaterial cohesion without any phase change in this temperature range, and fibres entanglement also acts like reinforcement. This panel could be used as inter-layer sheets for pallets or for the manufacturing of biodegradable containers (composters, crates for vegetable gardening) by assembly of panels.
\end{abstract}

\section{Introduction}

Twin-screw extrusion technology is an original and powerful solution for the biorefinery of sunflower whole plant $[1,2]$. Aqueous extraction of sunflower oil is chosen as an environmentfriendly alternative to the solvent extraction while the Clextral BC 45 (France) co-penetrating and co-rotating twin-screw extruder is used to carry out three essential unit operations in a single step and in a continuous mode: (i) conditioning and grinding of the whole plant, (ii) liquid/solid 
extraction, and (iii) liquid/solid separation. It is equipped with a filtration module to obtain separately an extract and a raffinate (cake meal).

In the best conditions, the oil yield is approximately $57 \%$ with a residual oil content in the cake meal of approximately $14 \%$. These conditions lead to the co-extraction of proteins but also pectins and hemicelluloses. The corresponding protein yield is approximately $44 \%$ while the residual protein content in the cake meal is approximately 7\%. The oil is extracted in the form of two different oil-in-water emulsions. These hydrophobic phases are stabilized by phospholipids and proteins at the interface, which are natural surface-active agents co-extracted during the process. An aqueous extract containing part of the water-soluble constituents from whole plant, mainly proteins and pectins, is also generated. The obtained fractions may have applications as bases for industrial products $[1,2]$.

The cake meal is relatively moist (more than 62\%). It is first dried to make easier its conservation. The cake meal contains notably cell debris from the kernel breakdown process. It has a porous structure and it is largely composed of lignocellulosic fibres (around 58\%) coming principally from the depithed stalk. Actually, the cake meal is a lixiviated matter where soluble molecules (proteins, pectins...) and lipids are partly removed. At the same time, molecules from plant skeleton are not extracted.

The cake meal is suitable for use in animal feeds and for energy production in pellets burning furnaces. Nevertheless, new valorisations of the cake meal as a mixture of lignocellulosic fibres and proteins can be also considered $[3,4]$.

This study aimed to show that it was possible to process the cake meal as a natural composite for the manufacturing of biodegradable and value-added agromaterials by thermo-pressing.

\section{Materials and methods}

Materials. Thermo-mechanical fractionation in the twin-screw extruder was carried out using two different batches of sunflower (Helianthus annuus Linnaeus) whole plant from oleic type (La Toulousaine de Céréales, France) (Table 1). The two batches were harvested in September, that is to say when the plant maturity was reached. Whole plant was previously dried in a ventilation oven $\left(50^{\circ} \mathrm{C}, 48 \mathrm{~h}\right)$ and crushed using a hammer mill (Electra VS 1, France) fitted with a $15 \mathrm{~mm}$ screen. Each batch of the powdered plant weighed around $250 \mathrm{~kg}$. The moisture content of the two batches was $5.0 \%$ and $6.0 \%$, respectively.

Table 1: Chemical composition of sunflower whole plant from the two batches used for experimental (\% of dry matter)

\begin{tabular}{ccc}
\hline Batch & 1 & 2 \\
\hline Minerals & $6.46 \pm 0.19$ & $6.41 \pm 0.12$ \\
Lipids & $26.83 \pm 0.43$ & $25.40 \pm 0.06$ \\
Proteins & $10.65 \pm 0.17$ & $10.79 \pm 0.12$ \\
Cellulose & $23.93 \pm 0.55$ & $23.16 \pm 0.07$ \\
Hemicelluloses & $7.83 \pm 0.09$ & $7.49 \pm 0.49$ \\
Lignins & $9.13 \pm 0.03$ & $10.43 \pm 0.18$ \\
\hline
\end{tabular}

Twin-screw extruder. Thermo-mechanical fractionation was conducted with a Clextral BC 45 (France) co-rotating twin-screw extruder. The extruder had seven modular barrels, each $200 \mathrm{~mm}$ in length, and different twin-screws which had segmental screw elements each 50 and $100 \mathrm{~mm}$ in length (Fig. 1). Four modules (modules 3, 4, 5 and 7) were heated to $80^{\circ} \mathrm{C}$ by thermal induction and cooled by water circulation. A filter section consisting of six hemispherical dishes with perforations $1 \mathrm{~mm}$ in diameter was outfitted on module 6 to enable the filtrates to be collected. Screw rotation speed $\left(S_{S}\right)$, the sunflower whole plant feed rate $\left(Q_{S}\right)$, and the barrel temperature $\left(\theta_{c}\right)$ were monitored from a control panel. 


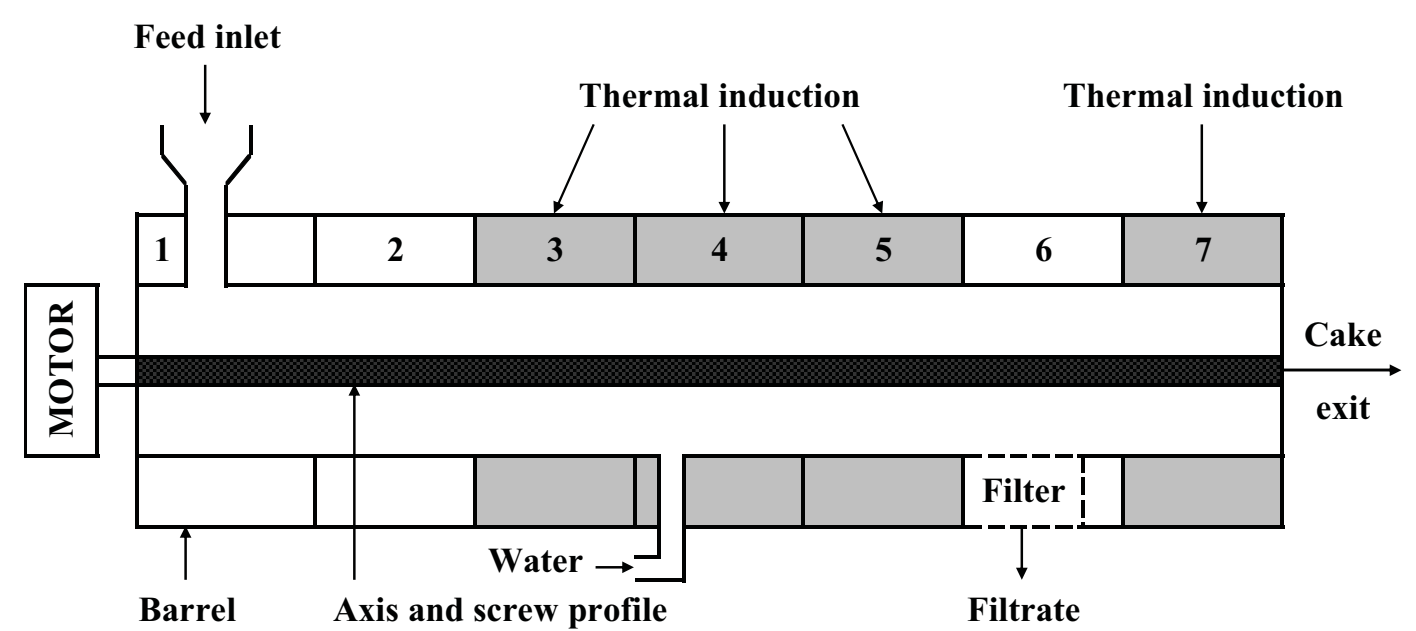

Fig. 1: Schematic modular barrel of the Clextral BC 45 twin-screw extruder used for thermo-mechanical fractionation of sunflower whole plant $\left(\theta_{\mathrm{c}}=80^{\circ} \mathrm{C}\right)$.

Thermo-mechanical fractionation of sunflower whole plant in the twin-screw extruder. Sunflower whole plant was fed into the extruder inlet port by a volumetric screw feeder (Clextral 40, France) located in module 1. Water was injected using a piston pump (Clextral DKM K20-2-P32, France) at the start of module 4 (Fig. 1). The only screw profile tested in this study (Fig. 2) was already used successfully for the direct aqueous extraction of oil from whole sunflower seeds [5]. The trituration zone was located in modules 2 and 3. It consisted of the succession of 10 monolobe paddles and 5 bilobe paddles, $5 \mathrm{~cm}$ apart. The extraction zone was situated in the modules 4 and 5. It was composed of a second series of 5 bilobe paddles. The reversed pitch screws were positioned in module 7, immediately downstream from the filtration module, to press the liquid/solid mixture.



$C 1 F$, conveying simple screw; DM, monolobe paddle-screw; BB, bilobe paddle-screw;

$C F 1 C$, reversed screw. The numbers following the type of the screw indicate the pitch of $T 2 F, C 2 F, C 1 F$ and CFIC screws and the length of the DM and BB screws.

Fig. 2: Screw configuration of the Clextral BC 45 twin-screw extruder used for thermo-mechanical fractionation of sunflower whole plant.

The extruder was left to function for 20 to 25 minutes before any sampling to ensure the stabilization of the operating conditions. Such conditions include feed flows of sunflower whole plant and water, temperature and current feeding the motor. Upon achieving steady operation, the filtrate and the cake meal were immediately collected over a period of 20 minutes to avoid any variability of the outlet flow rates. Sample collection time was determined with a stopwatch. For each test, sample collection was carried out once. The filtrate and the cake meal were weighed.

The oil yield was calculated according to the Eq. 1:

$$
\mathbf{R}_{\mathrm{L}}=\frac{\left(\mathbf{Q}_{\mathrm{s}} \times \mathrm{L}_{\mathrm{s}}\right)-\left(\mathbf{Q}_{\mathrm{C}} \times \mathbf{L}_{\mathrm{C}}\right)}{\left(\mathbf{Q}_{\mathrm{s}} \times \mathrm{L}_{\mathrm{S}}\right)} \times 100
$$




$$
\mathbf{R}_{\mathrm{P}}=\frac{\left(\mathbf{Q}_{\mathrm{S}} \times \mathbf{P}_{\mathrm{S}}\right)-\left(\mathbf{Q}_{\mathrm{C}} \times \mathbf{P}_{\mathrm{C}}\right)}{\mathbf{Q}_{\mathrm{S}} \times \mathbf{P}_{\mathrm{S}}} \times \mathbf{1 0 0}
$$

$\mathrm{R}_{\mathrm{P}}$ is the protein yield based on the residual protein content of the cake meal (\%), $\mathrm{P}_{\mathrm{S}}$ the protein content in the sunflower whole plant $(\%)$, and $\mathrm{P}_{\mathrm{C}}$ is the protein content in the cake meal (\%).

The energy consumed by the motor was determined according to the Eq. 3 and to the Eq. 4:

$$
P=U \times I \times \cos \varphi \times \frac{S_{S}}{S_{\text {max }}} .
$$

$P$ is the electric power supplied by the motor $(\mathrm{W}), \mathrm{U}$ the motor's operating voltage $(\mathrm{U}=460 \mathrm{~V})$, I the current feeding the motor $(\mathrm{A}), \cos \varphi$ the theoretical yield of the extruder motor $(\cos \varphi=0.95)$, and $S_{S}$ and $S_{\max }$ are the test speed and maximum speed $(600 \mathrm{rpm})$ of the rotating screws (rpm), respectively.

$$
\text { SME }=\frac{\mathbf{P}}{\mathbf{Q}_{\mathrm{S}}} .
$$

SME is the specific mechanical energy consumed by the motor per unit weight of sunflower whole plant ( $\mathrm{W} \mathrm{h} / \mathrm{kg})$.

Analytical methods. The moisture contents were determined according to the French standard NF $V$ 03-903. The mineral contents were determined according to the French standard NF V 03-322. The oil contents were determined according to the French standard NF V 03-908. The protein contents were determined according to the French standard NF V 18-100. An estimation of the three parietal constituents (cellulose, hemicelluloses, and lignins) contained in the solids was made by the ADF-NDF method of Van Soest and Wine [6,7]. All determinations were carried out in duplicate.

DSC analysis. Differential Scanning Calorimetry (DSC) analysis was used to evaluate the denaturation level of proteins, more specifically globulins, in the cake meal [8]. The study was performed on a PerkinElmer (USA) Pyris 1 power compensation calorimeter fitted with an intracooler cooling system. The purge gas used was nitrogen (flow rate of $20 \mathrm{~mL} / \mathrm{min}$ ). Temperature and energy calibration was carried out with indium $\left(\mathrm{T}_{\mathrm{f}}=156.6^{\circ} \mathrm{C}\right)$ and water $\left(\mathrm{T}_{\mathrm{f}}=0^{\circ} \mathrm{C}\right)$.

All analyses were performed with hermetic $60 \mu \mathrm{L}$ stainless steel capsules fitted out with O-rings resistant to an internal pressure of 40 bar (PerkinElmer, USA). Reference cell was empty. They were carried out at a heating speed of $20^{\circ} \mathrm{C} / \mathrm{min}$ from $25^{\circ} \mathrm{C}$ and stopped at $200^{\circ} \mathrm{C}$. Before analysis, samples were equilibrated in climatic chamber $\left(60 \% \mathrm{RH}, 25^{\circ} \mathrm{C}\right)$ during three weeks. The sample mass was around $10 \mathrm{mg}$ and all measurements were done in triplicate. Peak integration was realized with a sigmoid base line.

DMTA analysis. DMTA analysis was used to evaluate the thermo-mechanical behaviour of the cake meal and the one of the panels resulting from its thermo-pressing. DMTA experiments were carried out on a Triton Technology Tritec 2000 (UK) DMTA. DMTA analysis of the cake meal was realized in its milled powder. The powder was placed in a small metallic container, inert from the point of view of relaxations $(30.0 \mathrm{~mm} \times 7.0 \mathrm{~mm} \times 1.3 \mathrm{~mm})$. For the panels analyses, samples were $10 \mathrm{~mm}$ in width, and $30 \mathrm{~mm}$ in length. Before analysis, samples were dried in high vacuum, and with $\mathrm{P}_{2} \mathrm{O}_{5}\left(60^{\circ} \mathrm{C}, 3\right.$ days $)$. 
DMTA measurements were realized according to the two points bending technique with three different frequencies $(1 \mathrm{~Hz}, 5 \mathrm{~Hz}$ and $10 \mathrm{~Hz}), 100 \mu \mathrm{m}$ displacement, and a $3^{\circ} \mathrm{C} / \mathrm{min}$ heating rate on a -50 to $250^{\circ} \mathrm{C}$ range. Distance between the two points was $10 \mathrm{~mm}$.

PVT measurements. A Thermo electron corporation Haake pvT100 (Germany) fully automated high-pressure dilatometer was used for PVT measurements in the cake meal. The dilatometer was used to measure volume changes of the cake meal at controlled temperatures $\left(50\right.$ to $\left.200^{\circ} \mathrm{C}\right)$ and pressure (150 bar). The cake meal was crushed using a cutting mill (Ika Werke MF 10 basic, Germany) fitted with a $2 \mathrm{~mm}$ screen, and equilibrated in climatic chamber $\left(60 \% \mathrm{RH}, 25^{\circ} \mathrm{C}\right)$ during three weeks before being tested.

Then, it was put between two Teflon ${ }^{\circledR}$ joints in a vertical cylindrical chamber, closed by underside. The mass of the milled powder introduced inside the chamber $(230 \mathrm{mg})$ depended on its tapped density (0.3254) that was measured beforehand in a Granuloshop Densitap ETD-20 (France) volumenometer.

The evolution of the sample specific volume $\left(\mathrm{cm}^{3} / \mathrm{g}\right)$ and the one of its bulk density according to pressure and temperature applied were measured.

Thermo-pressing. The cake meal was molded by thermo-pressing between two aluminium plates covered with grease-proof paper, using a MAPA 50 (Pinette Emidecau Industries, France) heated hydraulic press. The moisture content of the cake meal was $4.4 \%$. The panels produced were $130 \mathrm{~mm} \times 130 \mathrm{~mm}$ squares.

Mechanical properties in bending. A $5-\mathrm{kN}$ H5KT (JFC, France) universal testing machine fitted with a $100 \mathrm{~N}$ load cell was used to assess the flexural properties of the test specimens according to the French standard NF EN 310, including flexural strength at break $\left(\sigma_{\mathrm{f}}\right)$ and elastic modulus $\left(\mathrm{E}_{\mathrm{f}}\right)$. The test specimens were $130 \mathrm{~mm}$ long and $30 \mathrm{~mm}$ wide. Their thickness was measured at three points with an electronic digital sliding caliper having a $0.01 \mathrm{~mm}$ resolution, and the mean value $(t)$ was recorded to calculate their volume and section. All specimens were weighed to calculate their mean apparent density $(\mathrm{d})$.

The test speed was $3 \mathrm{~mm} / \mathrm{min}$ and the grip separation was $100 \mathrm{~mm}$. Test specimens were cut, and equilibrated in climatic chamber $\left(60 \% \mathrm{RH}, 25^{\circ} \mathrm{C}\right)$ during three weeks before being tested.

Contact angle with water. Drop angle measurements were used to estimate the water sensibility of the panels resulting from the thermo-pressing of the cake meal. Panels were tested on a GBX Digidrop (France) contact angle meter. One drop of water $(3 \mu \mathrm{L})$ was placed on the test specimen. Left and right angles were measured at stable time intervals during $200 \mathrm{~s}$ (kinetics), and the value reported for each time was the average of these two angles. The curve reported was the average of five experiments. Test specimens used for analysis were cut, and equilibrated in climatic chamber $\left(60 \% \mathrm{RH}, 25^{\circ} \mathrm{C}\right)$ during three weeks before being tested.

\section{Results and discussion}

Thermo-mechanical fractionation of sunflower whole plant in the twin-screw extruder. Thermo-mechanical fractionation and aqueous extraction were conducted in the twin-screw extruder simultaneously. The biorefinery of sunflower whole plant was realized in a single step because a filter section was outfitted along the barrel (module 6) to collect continuously an extract and a raffinate (cake meal). Lipids and water-soluble constituents (mainly proteins but also pectins and hemicelluloses) were partly extracted during the process.

Its efficiency depended mostly on the operating conditions including screw rotation speed and inlet flow rates of whole plant and water, but also probably on the batch used for the corresponding trial (Table 2). The batch used for trial 1 was the first one. Oil yield and protein yield obtained were then $65 \%$ and $55 \%$, respectively. Trial 2 was realized with the second batch of whole plant. Oil yield and protein yield obtained were then $60 \%$ and $47 \%$, respectively. In fact, taking into account the oil and protein contents in the foot of the filtrate [2], oil yield and protein yield were lower. As 
an example, in the case of trial 1 , oil corrected yield and protein corrected yield were $53 \%$ and $46 \%$, respectively.

Consequently, trial 1 appeared to be more efficient. This could be explained by the higher ratio of the water to the whole plant inside the extruder (4.0 instead of 3.5 for trial 2) that improved the mass transfer during the liquid/solid extraction. Even if the device's filling coefficient was lower for trial 1 ( 0.08 instead of 0.12 for trial 2), it seemed to be sufficient to allow an efficient liquid/solid separation of the extract and the cake meal at the level of the reversed screws.

Table 2: Results of the thermo-mechanical fractionation experiments conducted with the Clextral BC 45 twin-screw extruder and using the sunflower whole plant $\left(\theta_{\mathrm{c}}=80^{\circ} \mathrm{C}\right)$

\begin{tabular}{|c|c|c|}
\hline Trial & 1 & 2 \\
\hline \multicolumn{3}{|l|}{ Operating conditions } \\
\hline Batch & 1 & 2 \\
\hline $\mathrm{S}_{\mathrm{S}}(\mathrm{rpm})$ & 60 & 60 \\
\hline $\mathrm{Q}_{\mathrm{S}}(\mathrm{kg} / \mathrm{h})$ & 5.0 & 7.1 \\
\hline $\mathrm{Q}_{\mathrm{W}}(\mathrm{kg} / \mathrm{h})$ & 20.3 & 24.5 \\
\hline $\mathrm{Q}_{\mathrm{W}} / \mathrm{Q}_{\mathrm{S}}$ & 4.0 & 3.5 \\
\hline $\mathrm{C}_{\mathrm{F}}(\mathrm{kg} / \mathrm{h} \mathrm{rpm})$ & 0.08 & 0.12 \\
\hline \multicolumn{3}{|l|}{ Filtrate } \\
\hline $\mathrm{Q}_{\mathrm{F}}(\mathrm{kg} / \mathrm{h})$ & 15.8 & 18.6 \\
\hline \multicolumn{3}{|l|}{ Cake meal } \\
\hline $\mathrm{Q}_{\mathrm{C}}(\mathrm{kg} / \mathrm{h})$ & 9.6 & 13.0 \\
\hline $\mathrm{H}_{\mathrm{C}}(\%)$ & $65.75 \pm 0.11$ & $63.71 \pm 0.01$ \\
\hline $\mathrm{L}_{\mathrm{C}}(\%$ of dry matter $)$ & $13.15 \pm 0.04$ & $14.46 \pm 0.01$ \\
\hline $\mathrm{P}_{\mathrm{C}}(\%$ of dry matter $)$ & $6.72 \pm 0.08$ & $8.02 \pm 0.01$ \\
\hline $\mathrm{CL}_{\mathrm{C}}(\%$ of dry matter $)$ & $45.64 \pm 0.70$ & $45.68 \pm 0.54$ \\
\hline \multicolumn{3}{|l|}{ Oil yields $(\%)$} \\
\hline $\mathrm{R}_{\mathrm{L}}$ & 64.9 & 59.7 \\
\hline $\mathrm{R}_{\mathrm{L}}$ & 53.2 & n.d. \\
\hline \multicolumn{3}{|l|}{ Protein yields (\%) } \\
\hline $\mathrm{R}_{\mathrm{P}}$ & 54.9 & 47.4 \\
\hline $\mathrm{R}_{\mathrm{P}}$ & 46.3 & n.d. \\
\hline \multicolumn{3}{|l|}{ Energy consumed } \\
\hline $\mathrm{I}(\mathrm{A})$ & 14.8 & 15.9 \\
\hline $\mathrm{P}(\mathrm{W})$ & 644.6 & 693.7 \\
\hline SME $(\mathrm{W} \mathrm{h} / \mathrm{kg})$ & 128.5 & 97.9 \\
\hline \multicolumn{3}{|c|}{$\begin{array}{l}Q_{W} \text { is the inlet flow rate of the water }(\mathrm{kg} / \mathrm{h}) . C_{F} \text { is the device's filling coefficient } \\
(\mathrm{kg} / \mathrm{h} \mathrm{rpm}) ; \text { it is defined as the ratio of the inlet flow rate of the sunflower whole plant } \\
\left(Q_{S}\right) \text { to the screw rotation speed }\left(S_{S}\right) . Q_{F} \text { is the flow rate of the filtrate }(\mathrm{kg} / \mathrm{h}) . H_{C} \text { is the } \\
\text { moisture content in the cake meal }(\%) \text {. C } L_{C} \text { is the cellulose and lignins content in the } \\
\text { cake meal }(\%) . R_{L} \text { ' and } R_{P} \text { ' are the oil corrected yield and the protein corrected yield; } \\
\text { they also take into account the oil and protein contents in the foot of the filtrate. } \\
\text { n.d. = non determined. }\end{array}$} \\
\hline
\end{tabular}

The higher specific mechanical energy consumed by the motor was also indicative of the better efficiency of trial 1: $128.5 \mathrm{~W} \mathrm{~h} / \mathrm{kg}$ instead of $97.9 \mathrm{~W} \mathrm{~h} / \mathrm{kg}$ for trial 2 (Table 2). Thus, the impoverishment of the cake meal in lipids and proteins was a little better for trial 1 . Indeed, residual oil content of the cake meal was $13.1 \%$ for trial 1 and $14.5 \%$ for trial 2 . At the same time, residual protein content of the cake meal was $6.7 \%$ for trial 1 and $8.0 \%$ for trial 2 . In both cases, the cake 
meal was also largely composed of lignocellulosic fibres from the depithed stalk [9]. As an example, for the cake meal from trial 1, fibres represented $59 \%$ of its dry matter [2]. Moreover, the only cellulose and lignins represented $46 \%$ of the two raffinates (Table 2). Lastly, the cake meal was relatively moist (64\% at least for its moisture content), and it was first dried $\left(105^{\circ} \mathrm{C}, 24 \mathrm{~h}\right)$ to make easier its conservation.

Thermo-mechanical behaviour of the cake meal. The cake meal chosen for the study of its thermo-mechanical behaviour originated from trial 1. DSC measurements indicated that the denaturation of proteins seemed to be almost complete in the cake meal.

However, the quantitative comparison of the two average denaturation enthalpies (Table 3: $6.6 \mathrm{~J} / \mathrm{g}$ of dry protein in the sunflower whole plant and only $1.0 \mathrm{~J} / \mathrm{g}$ of dry protein in the cake meal from trial 1) was delicate. Indeed, proteins were partly and selectively extracted by water in the twin-screw extruder. Consequently, selective extraction of proteins probably led to a difference in the distribution of the four families of sunflower proteins (albumins, globulins, glutelins, and prolamins) between the whole plant and the cake meal. Thus, the comparison of the two denaturation levels of proteins could be only qualitative.

Table 3: Average temperature, average enthalpy reported to the sample mass, to the mass of dry matter and to the mass of dry protein of the denaturation peak observed on DSC scans of sunflower whole plant (batch 1) and cake meal from trial 1, in pressure resistant pans

\begin{tabular}{ccc}
\hline & Sunflower whole plant (batch 1) & Cake meal from trial 1 \\
\hline Moisture content $(\%)$ & $7.09 \pm 0.03$ & $7.91 \pm 0.16$ \\
\hline Peak temperature $\left({ }^{\circ} \mathrm{C}\right)$ & $151.7 \pm 0.5$ & $140.4 \pm 0.4$ \\
\hline Enthalpy $(\mathrm{J} / \mathrm{g}$ of sample) & $0.66 \pm 0.02$ & $0.07 \pm 0.00$ \\
Enthalpy $(\mathrm{J} / \mathrm{g}$ of dry matter $)$ & $0.71 \pm 0.02$ & $0.07 \pm 0.00$ \\
Enthalpy $(\mathrm{J} / \mathrm{g}$ of dry protein) & $6.56 \pm 0.21$ & $1.00 \pm 0.04$ \\
\hline
\end{tabular}

DMTA analysis of the cake meal was realized in its milled powder. The most significant vibratory oscillation peak was observed at the highest temperature (between 175 and $200^{\circ} \mathrm{C}$ ) (Fig. 3). As for industrial sunflower cake meal [4], it was associated with the glass transition of proteins from kernel. The two other peaks appeared at lower temperatures (between 35 and $60^{\circ} \mathrm{C}$ for the first one, and between 115 and $125^{\circ} \mathrm{C}$ for the second one). They could correspond to the thermal transition phenomena of pectins, hemicelluloses or lignins, located in the fibres from kernel, hull and stalk [2].

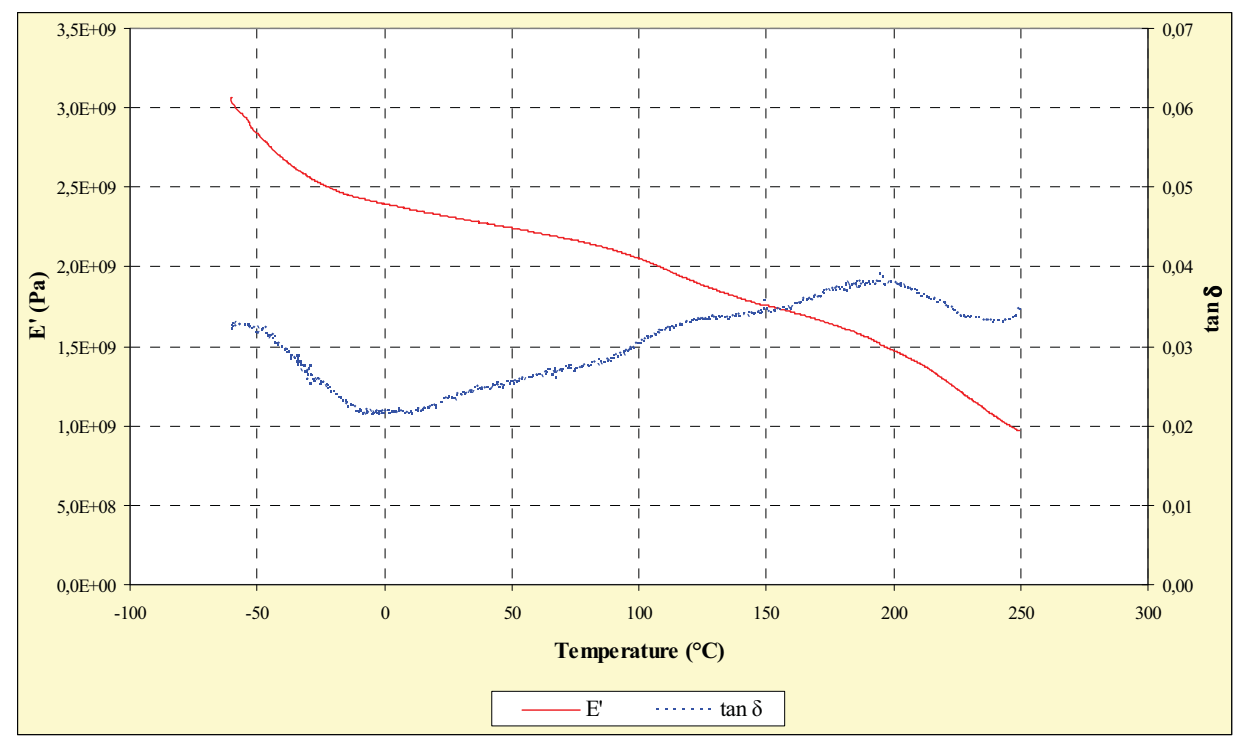

Fig. 3: DMTA spectrum at $1 \mathrm{~Hz}$ of the cake meal from trial 1 (E', conservation modulus; E', loss modulus; $\tan \delta=$ E''/E'). 
Consequently, the cake meal was a mixture of lignocellulosic fibres and proteins with thermoplastic properties. Thus, it was considered as a natural composite, and its thermo-pressing became a promising molding operation for the manufacturing of biodegradable and value-added agromaterials.

Thermo-pressing of the cake meal for the manufacturing of biodegradable agromaterials. The cake meal chosen for the manufacturing of biodegradable agromaterials by thermo-pressing originated from trial 2. As for DMTA analysis (Fig. 3), the glass transition of proteins was observed with PVT analysis at around $180^{\circ} \mathrm{C}$ (Fig. 4). Another transition also appeared at lower temperature (around $140^{\circ} \mathrm{C}$ ). It was less significant than the first one but it could be also associated with proteins [2]. PVT analysis made easier the choice of the best thermo-pressing conditions to produce panels with mechanical properties in bending as high as possible (Table 4).

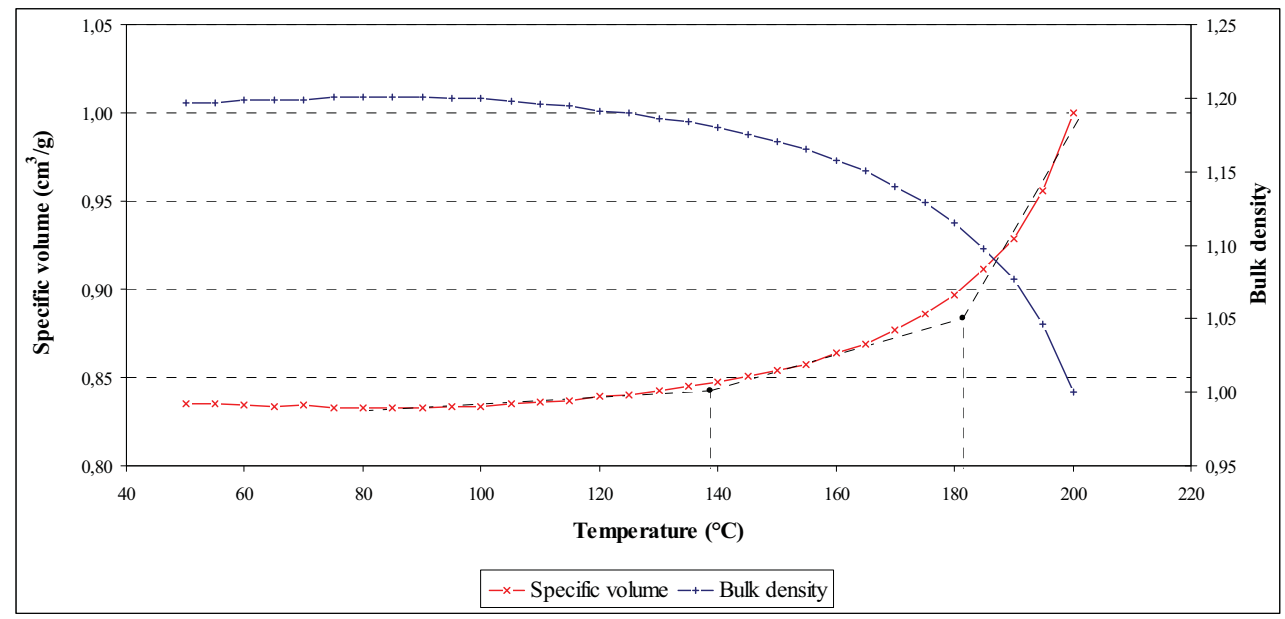

Fig. 4: PVT measurements realized on the cake meal from trial 2 at controlled temperatures $\left(50\right.$ to $\left.200^{\circ} \mathrm{C}\right)$ and pressure $(150 \mathrm{bar})$.

These properties increased simultaneously with temperature, pressure and time chosen for molding operation. Thus, the highest flexural strength at break (11.5 MPa) and the highest elastic modulus $(2.22 \mathrm{GPa})$ were obtained for the panel $5\left(200^{\circ} \mathrm{C}\right.$ and $320 \mathrm{kgf} / \mathrm{cm}^{2}$ during $\left.60 \mathrm{~s}\right)$ (Table 4). The mean apparent density of the agromaterial was 1.04 for this panel.

Table 4: Thermo-pressing conditions and mechanical properties in bending ( $\sigma_{\mathrm{f}}$, flexural strength at break; $\mathrm{E}_{\mathrm{f}}$, elastic modulus) of the molded test specimens

\begin{tabular}{lccccc}
\hline Panel & 1 & 2 & 3 & 4 & 5 \\
\hline Thermo-pressing conditions & & & & & \\
Temperature $\left({ }^{\circ} \mathrm{C}\right)$ & 160 & 160 & 160 & 180 & 200 \\
Pressure $\left(\mathrm{kgf} / \mathrm{cm}^{2}\right)$ & 107 & 320 & 320 & 320 & 320 \\
Time $(\mathrm{s})$ & 30 & 30 & 60 & 60 & 60 \\
& & & & & \\
Flexural properties & & & & & \\
t $(\mathrm{mm})$ & $0.01 \pm 0.39$ & $3.97 \pm 0.19$ & $3.82 \pm 0.12$ & $3.88 \pm 0.18$ & $3.89 \pm 0.15$ \\
$\mathrm{~d}$ & $0.74 \pm 0.05$ & $1.09 \pm 0.05$ & $1.13 \pm 0.04$ & $1.09 \pm 0.05$ & $1.04 \pm 0.04$ \\
$\sigma_{\mathrm{f}}(\mathrm{MPa})$ & $0.4 \pm 0.1$ & $5.0 \pm 0.2$ & $6.0 \pm 1.0$ & $11.3 \pm 0.9$ & $11.5 \pm 0.5$ \\
$\mathrm{E}_{\mathrm{f}}(\mathrm{GPa})$ & $0.10 \pm 0.03$ & $1.07 \pm 0.15$ & $1.28 \pm 0.19$ & $2.11 \pm 0.16$ & $2.22 \pm 0.17$ \\
\hline
\end{tabular}

For all the panels, the contact angle with water was always under $90^{\circ}$ (Fig. 5), even at the beginning of the kinetics $(t=0)$. It also decreased rapidly with time. This indicated that all the panels had a hydrophilic character and that they were highly water-sensitive. Nevertheless, the panel with the highest mechanical properties in bending (panel 5) was also the most resistant to water. 
Indeed, the contact angle with water was still $35^{\circ}$ after $160 \mathrm{~s}$ for the panel 5 while the drop of water disappeared completely inside the agromaterial in less than $20 \mathrm{~s}$ for the panels 1 to 4 (Fig. 5).

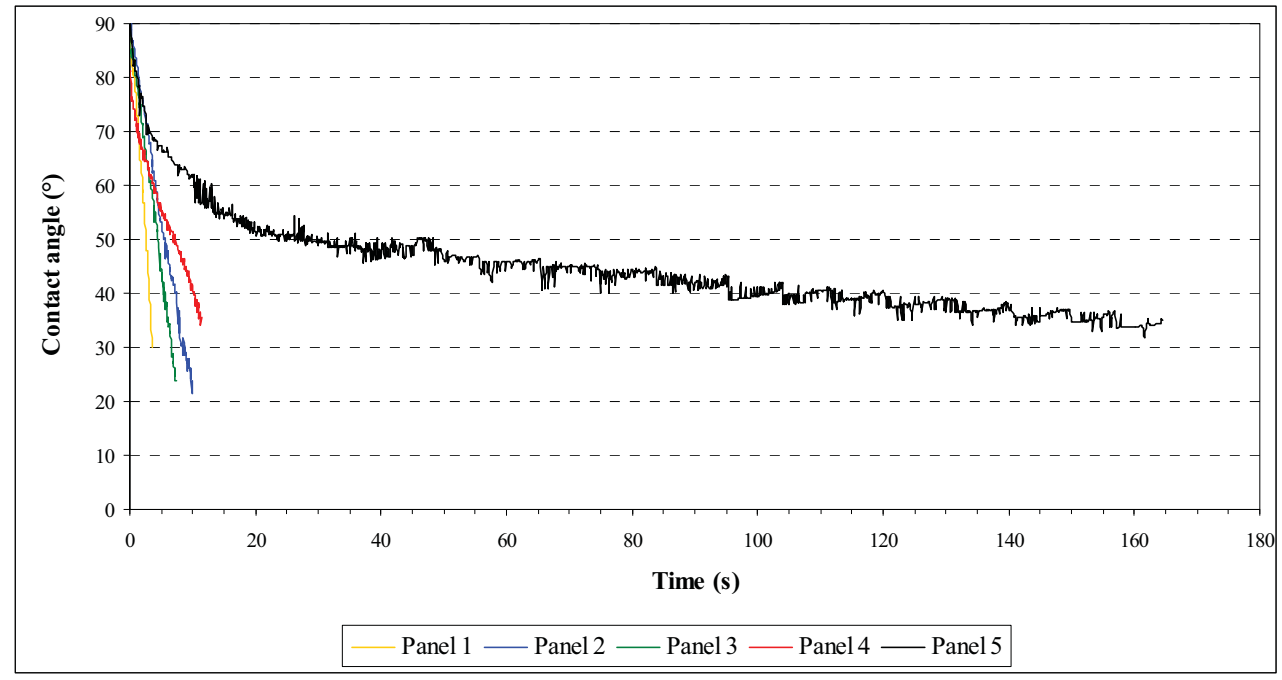

Fig. 5: Average contact angle with water as a function of time for the panels 1 to 5 .

During the molding of panel 5, the macromolecular structure of proteins was completely transformed due to their thermal sensibility, leading to their glass transition under the simultaneous effect of pressure and temperature. Under those thermopressing conditions, the residual or neocrystalline structure of proteins was also probably irreversibly destroyed, and it certainly melted. The reorganization of the structure of proteins allowed the mechanical aspect of the panel and gave to the agromaterial its flexibility while the fibres entanglement also acted like reinforcement.

DMTA analysis of the panels 2 to 5 indicated that the highest values of the conservation modulus (E') were obtained for the panel 5 (Fig. 6). At the same time, tan $\delta$ values recorded for this panel were the lowest. This confirmed that it was the most cohesive panel. For all the panels tested, a significant vibratory oscillation peak appeared at low temperature (between -20 and $-14^{\circ} \mathrm{C}$ ). It could be attributed to the $\beta$-transition of the proteins (glass transition of their side chains) [10, 11]. Moreover, no additional significant transition was observed above $0^{\circ} \mathrm{C}$ and until $200^{\circ} \mathrm{C}$. No phase change happened in this temperature range and proteins still ensured the agromaterial cohesion. Beyond $200^{\circ} \mathrm{C}$, the panel degradation probably occurred.

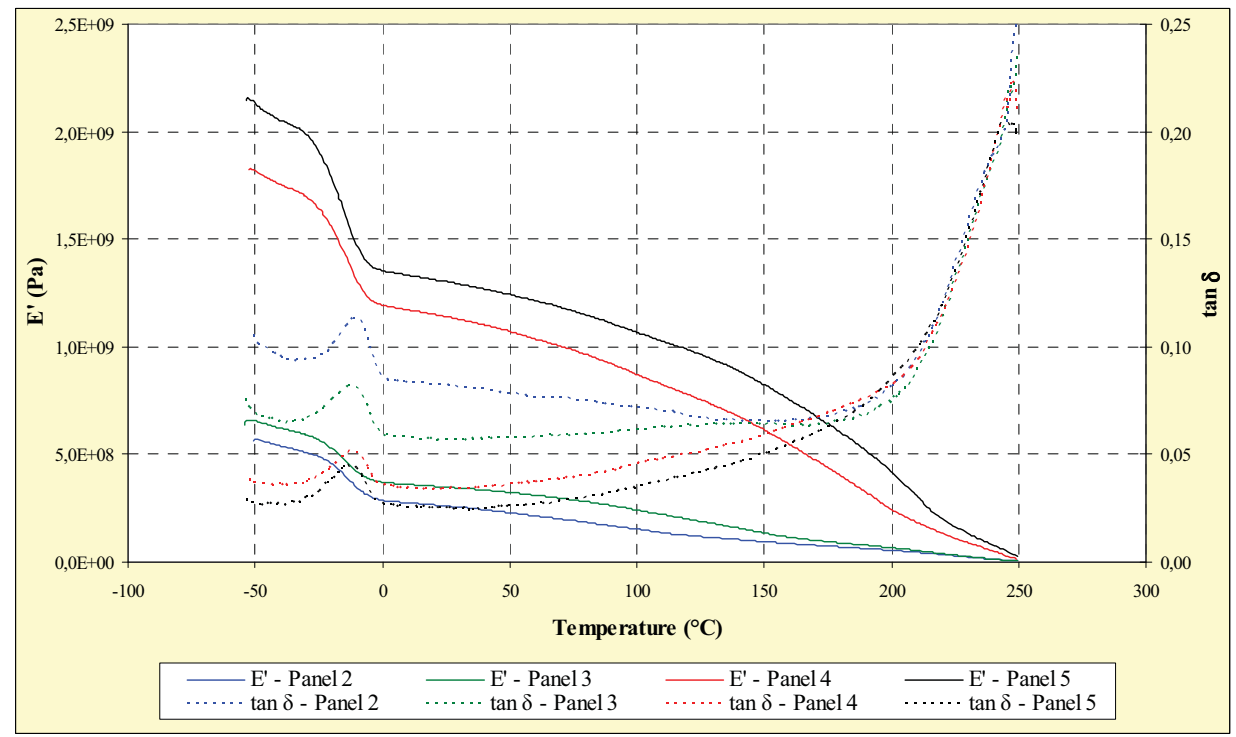

Fig. 6: DMTA spectrum at $10 \mathrm{~Hz}$ of the panels 2 to 5 . 
Because of their promising mechanical properties in bending compared with those of other experimental materials, such panels could be used as inter-layer sheets for pallets in the handling and storage industry or for the manufacturing of biodegradable containers (composters, crates for vegetable gardening) by assembly of panels.

\section{Conclusion}

The cake meal resulting from the aqueous extraction of sunflower whole plant in a co-penetrating and co-rotating twin-screw extruder was a mixture of lignocellulosic fibres and proteins. Therefore, it could be considered as a natural composite. Its molding into biodegradable agromaterials was carried out successfully by thermo-pressing. Panels manufactured had promising mechanical properties in bending, and proteins ensured their cohesion. The highest flexural strength at break $(11.5 \mathrm{MPa})$ was obtained for the highest values of temperature, pressure and time chosen for molding operation. The corresponding panel was also the most resistant to water in spite of its hydrophilic character. Its thermo-mechanical behaviour was studied through DMTA experiments. It revealed that no significant transition occurred above $0^{\circ} \mathrm{C}$ and until $200^{\circ} \mathrm{C}$. Consequently, it would be interesting to use it as inter-layer sheets for pallets or for the manufacturing of biodegradable containers.

\section{References}

[1] Ph. Evon, V. Vandenbossche, P.Y. Pontalier and L. Rigal: Proceedings of the $15^{\text {th }}$ European Biomass Conference \& Exhibition, Berlin, Germany (2007), pp. 2094-2098.

[2] Ph. Evon, Ph.D. thesis, INP, Toulouse, France (2008).

[3] F. Silvestre, A. Gaset, L. Rigal and J. Leyris, European Patent 0,987,089 (2000).

[4] C. Geneau, Ph.D. thesis, INP, Toulouse, France (2006).

[5] Ph. Evon, V. Vandenbossche, P.Y. Pontalier and L. Rigal: Ind. Crops Prod. Vol. 26 (2007), pp. 351-359.

[6] P.J. Van Soest and R.H. Wine: J. Am. Oil Chem. Soc. Vol. 50 (1967), pp. 50-55.

[7] P.J. Van Soest and R.H. Wine: J. Am. Oil Chem. Soc. Vol. 51 (1968), pp. 780-784.

[8] A. Rouilly, O. Orliac, F. Silvestre and L. Rigal: Thermochim. Acta Vol. 398 (2003), pp. 195-201.

[9] V. Maréchal and L. Rigal: Ind. Crops Prod. Vol. 10 (1999), pp. 185-200.

[10] J. Zhang, P. Mungara and J. Jane: Polymer Vol. 42 (2001), p. 2569.

[11] A. Rouilly, A. Mériaux, C. Geneau, F. Silvestre and L. Rigal: Polym. Eng. Sci. Vol. 46 (2006), pp. 1635-1640. 